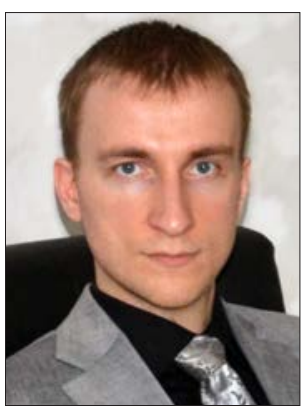

Oleksandr V. Blintsov

Блінцов

Олександр

Володимирович

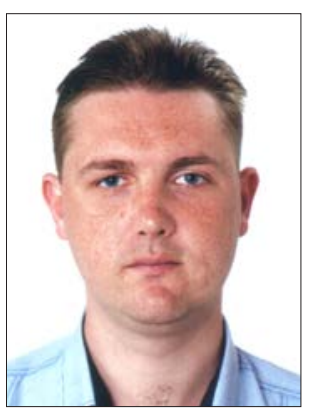

Viktor

I. Korytskyi

Корицький

Віктор

Ігорович

УДК 629.58:681.5

\section{DESIGN OF AUTOMATIC CONTROL SYSTEM OF SPATIAL MOTION OF A REMOTELY OPERATED UNDERWATER VEHICLE UNDER UNCERTAINTY CONDITIONS}

\section{РОЗРОБКА СИСТЕМИ АВТОМАТИЧНОГО КЕРУВАННЯ ПРОСТОРОВИМ РУХОМ ТЕЛЕКЕРОВАНОГО ПІДВОДНОГО АПАРАТА В УМОВАХ НЕВИЗНАЧЕНОСТІ}

DOI https:// doi.org/10.15589/smi2019.1(11).10

Oleksandr V. Blintsov

Блінцов Олександр Володимирович, докт. техн. наук, доц. alex_blintsov@ukr.net ORCID: 0000-0003-0426-1219

Viktor I. Korytskyi

Корицький Віктор Ігорович, викладач vic.koritskiy@gmail.com ORCID: 0000-0002-9968-1568

\section{Admiral Makarov National University of Shipbuilding, Mykolaiv \\ Національний університет кораблебудування імені адмірала Макарова, м. Миколаїв}

Abstract. Aim. In the paper an automated control system of a spatial motion of a remotely operated underwater vehicle that provides high quality of control processes under the conditions of uncertainty and constraints is designed. Methodology. To address the task of the automation of the control of spatial motion of underwater vehicle, multidimensional control law based on the minimization of local functionals performed by the method of gradient search of second order is synthesized. To provide high quality of motion control of underwater vehicle under the conditions of constraints, a new system component - an intensity setter based on multidimensional linear model of the plant and a regulator that is synthesized using the method of inverse dynamics is introduced. Results. To prove the operability of proposed system the simulation of the motion of an underwater vehicle with four controllable degrees of freedom is performed. Automated control system provides transient processes with duration that doesn't exceed $4 \mathrm{~s}$ and overshoots that don't exceed $2 \%$ of operation area boundaries. After the end of transient processes system follows the setpoint that changes dynamically with relative error that is less than $0,3 \%$ of operation area boundaries. Scientific novelty. In the paper multidimensional control law for a remotely operated underwater vehicle under the conditions of uncertainty based on the pseudo-inverse matrix of the configuration of propulsive complex and the minimization of local functionals performed by the method of gradient search is synthesized. Proposed system may be used to control a remotely operated underwater vehicle with arbitrary configuration of its propulsive complex. The setpoint intensity setter based on multidimensional linear model of the plant and an inverse regulator is synthesized. The usage of intensity setter as the element of automated control system improves the quality of the processes of control of the spatial motion of the remotely operated underwater vehicle under the conditions of constraints. Using proposed control law and multidimensional intensity setter the system of automated control of the spatial motion of the remotely operated underwater vehicle that provides high qualityof the processes of the control of its spatial motion under the conditions of uncertainty, constrained control signals and the influence of external disturbances is synthesized.Practical significance. Proposed system may be used to control a remotely operated underwater vehicle with arbitrary configuration of its propulsive complex. The automated control system provides high dynamic precision of control under the conditions of uncertainty and constraints. Moreover, for the automated control system to function properly the measurements of controlled variables will suffice, the measurement or estimation of derivatives of controlled variables is not necessary.

Key words: multidimensional automatic control system, integral saturation, conditions of uncertainty, remotely operated underwater vehicle.

Анотація. Мета. У роботі розроблено систему автоматичного керування просторовим рухом телекерованого підводного апарата, яка забезпечує високу якість процесів керування в умовах обмежень та невизначеності. Методика. Для вирішення задачі автоматизації керування просторовим рухом телекерованого підводного апарата запропоновано багатовимірний закон керування на основі мінімізації локальних 
функціоналів методом градієнтного пошуку другого порядку. Високу якість керування рухом підводного апарата в умовах обмежень забезпечено введенням до системи задавача інтенсивності, який побудовано на основі багатовимірної лінійної моделі об'єкта керування та регулятора, який синтезовано методом оберненої динаміки. Результати. Працездатність запропонованої системи підтверджено методом імітаційного моделювання просторового руху телекерованого підводного апарата із чотирма керованими ступенями рухливості. Система автоматичного керування забезпечує перехідні процеси, тривалість яких не перевищує 4 с, 3 перерегулюваннями, які не перевищують 2\% від межі робочої зони. Після завершення перехідного процесу система відпрацьовує задачу керування, що динамічно змінюється з відносною похибкою, яка не перевищує 0,3\% від межі робочої зони. Наукова новизна. У роботі синтезовано багатовимірний закон керування телекерованим підводним апаратом в умовах невизначеності із застосуванням псевдооберненої матриці конфігурації рушійного комплексу та методу мінімізації локального функціоналу на основі градієнтного пошуку. Запропонована система може бути використана для керування телекерованим підводним апаратом 3 довільною конфігурацією рушійного комплексу. Синтезовано задавач інтенсивності задачі керування на основі багатовимірної лінійної моделі об’єкта керування та інверсного регулятора. Його застосування у складі системи автоматичного керування дає змогу покращити якість процесів керування просторовим рухом телекерованого підводного апарата в умовах обмежень. На основі запропонованого закону керування та багатовимірного задавача інтенсивності синтезовано систему автоматичного керування просторовим рухом телекерованого підводного апарата, яка забезпечує високу якість процесів керування його просторовим рухом в умовах невизначеності, обмежень керуючих впливів та впливу зовнішніх збурень. Практична значимість. Запропонована система може бути використана для керування телекерованим підводним апаратом з довільною конфігурацією рушійного комплексу. Система автоматичного керування забезпечує високу динамічну точність керування в умовах невизначеності та обмежень. При цьому для функціонування системи керування достатньо вимірювати лише керовані параметри, а вимірювання або обчислення похідних керованих параметрів не потрібне.

Ключові слова: багатовимірна система автоматичного керування, інтегральне насичення, умови невизначеності; телекерований підводний апарат.

\section{References}

[1] Antonelli, G. (2018). Underwater Robots. Springer Tracts in Advanced Robotics. doi: 10.1007/978-3-319-77899-0.

[2] Korytskyi, V. I. (2018) Improvement of the Mathematical Model of Spatial Motion of a Remotely Operated Underwater Vehicle with Technological Equipment. Shipbuilding and Marine Infrastructure, 1 (9), 44-52. doi: 10.15589/ SMI.2018.01.06.

[3] Aras, M. S., Abdullah, S. S., Rahman, A. A., \& Aziz, M. A. (2013). Thruster Modelling for Underwater Vehicle Using System Identification. International Journal of Advanced Robotic Systems, 10 (252), 12. doi: 10.5772/56432.

[4] Liu, Z., Zhang, Y., Yu, X., \& Yuan, C. (2016). Unmanned surface vehicles: An overview of developments and challenges. Annual Reviews in Control, 41, 71-93. doi: 10.1016/j.arcontrol.2016.04.018.

[5] Stern, F., Yang, J., Wang, Z., Sadat-Hosseini, H., Mousaviraad, M., Bhushan, S., \& Xing, T. (2013). Computational ship hydrodynamics: nowadays and way forward. International Shipbuilding Progress, 60, 3-105. doi: 10.3233/ISP-130090.

[6] Fossen, T. I. (2011). Handbook of Marine Craft Hydrodynamics and Motion Control. John Wiley and Sons. doi: 10.1002/9781119994138.

[7] Park, J., \& Kim, N. (2015). Dynamics modeling of a semi-submersible autonomous underwater vehicle with a towfish towed by a cable. International Journal of Naval Architecture and Ocean Engineering, 7, 409-425. doi: 10.1515/ ijnaoe-2015-0029.

[8] Gayvoronskiy, S. A., Khozhaev, I. V., \& Ezangina, T. A. (2017). Motion Control System for a Remotely Operated Vehicle with Interval Parameters. International Journal of Mechanical Engineering and Robotics Research, 6:5, 378384. doi: 10.18178/ijmerr.6.5.378-384.

[9] Rúa, S., \& Vásquez, R. E. (2016). Development of a low-level control system for the ROV Visor3. International Journal of Navigation and Observation, 12. doi: 10.1155/2016/8029124.

[10] Yu, C., Xiang, X., Zhang, Q., \& Xu, G. (2018). Adaptive Fuzzy Trajectory Tracking Control of an Under-Actuated Autonomous Underwater Vehicle Subject to Actuator Saturation. International Journal of Fuzzy Systems, 20 (1), 269 279. doi: 10.1007/s40815-017-0396-9.

[11] Herman, P., \& Adamski, W. (2017). Non-adaptive velocity tracking controller for a class of vehicles. Bulletin of the Polish Academy of Sciences. Technical Sciences, 65:4, 459-468. doi: 10.1515/bpasts-2017-0051.

[12] Wang, G., Xu, G., Liu, G., Wang, W., \& Li, B. (2019). Fuzzy Iterative Sliding Mode Control Applied for Path Following of an Autonomous Underwater Vehicle with Large Inertia. Mathematical Problems in Engineering, 14. doi: $10.1155 / 2019 / 8650243$.

[13] Guerrero, J., Torres, J., Creuze, V., \& Chemori, A. (2019). Trajectory tracking for autonomous underwater vehicle: An adaptive approach. Ocean Engineering, 172, 511-522. doi: 10.1016/j.oceaneng.2018.12.027. 
[14] Xia, G., Pang, C., \& Xue, J. (2015). Fuzzy neural network-based robust adaptive control for dynamic positioning of underwater vehicles with input dead-zone. Journal of Intelligent and Fuzzy Systems, 29, 2585-2595. doi: 10.3233/ IFS-151961.

[15] Hernández-Alvarado, R., García-Valdovinos, L. G., Salgado-Jiménez, T., Gómez-Espinoza, A., \& Fonseca-Navarro, F. (2016). Neural Network-Based Self-Tuning PID Control for Underwater Vehicles. Sensors, 16, 18. doi: 10.3390/ s16091429.

[16] Chu, Z., Zhu, D., \& Luo, C. (2017). Adaptive Neural Sliding Mode Trajectory Tracking Control for Autonomous Underwater Vehicle Without Thrust Model. Materials of 13th IEEE Conference on Automation Science and Engineering. Xi`an, China, 1639-1644. doi: 10.1109/COASE.2017.8256339.

[17] Yang, C., Yao, F., \& Zhang, M. (2018). Adaptive Backstepping Terminal Sliding Mode Control Method Based on Recurrent Neural Networks for Autonomous Underwater Vehicle. Chinese Journal of Mechanical Engineering, 31 (110), 16. doi: 10.1186/s10033-018-0307-5.

[18] Li, X., Zhao, M., \& Ge, T. (2018). A Nonlinear Observer for Remotely Operated Vehicles with Cable Effect in Ocean Currents. Applied Sciences, 8:6, 27. doi: 10.3390/app8060867.

[19] Yao, F., Yang, C., Liu, X., \& Zhang, M. (2018). Experimental Evaluation on Depth Control Using Improved Model Predictive Control for Autonomous Underwater Vehicle (AUVs). Sensors, 18, 16.doi: 10.3390/s18072321.

[20] Blintsov, O. V. (2018). Systemy avtomatychnoho keruvannia rukhom pidvodnykh kompleksiv z hnuchkymy zviazkamy: navchalnyi posibnyk [Automatic Control Systems of the Motion of Underwater Complexes with Flexible Connections: tutorial]. Mykolaiv: Natsionalnyi universytet korablebuduvannia imeni admiral Makarova (in Ukrainian).

[21] Pavlov, H. V., \& Blintsov, O. V. (2008). Syntez neiromerezhnykh modelei elektrorushiinoho prystroiu dlia zadach keruvannia kvazistatsionarnym rukhom pryviaznoho pidvodnoho aparata [Synthesis of neural-network models of thruster in tasks of control of quasistationary motion of tethered underwater vehicle]. Zbirnyk naukovykh prats Natsionalnoho universytetu korablebuduvannia, 5 (422), 81-86 (in Ukrainian).

[22] Pshikhopov, V. Kh., Medvedev, M. Yu., Fedorenko, R. V., Gurenko, B. V., Chufistov, V. M., \& Shevchenko, V.A. (2014). Algoritmy mnogosvyaznogo pozitsionno-trayektornogo upravleniya podvizhnymi obyektami[Algorithms for multi-linked positionaland trajectorycontrolofmobileobjects].InzhenernyyvestnikDona,31(3), 17.Retrievedfromhttp://www.ivdon.ru/ uploads/article/pdf/IVD_26_Pshikhopov.pdf_ddf06b616a.pdf (in Russian).

[23] Blintsov, O., Korytskyi, V., \& Sokolov, V. (2019). Synthesis of Precise Automatic Control System of a Second Order Object in Uncertainty Conditions. ARPN Journal of Engineering and Applied Sciences, 14 (6), 1218-1228. Retrieved from http://www.arpnjournals.org/jeas/research_papers/rp_2019/jeas_0319_7671.pdf.

[24] Blintsov, O. V., Burunina, Zh. Yu., \& Voitasyk, A. M. (2019). Improvement of the Inverse Dynamics Method for High-Precision Control of Nonlinear Objects under Conditions of Uncertainty. Eastern-European Journal of Enterprise Technologies, 2/2 (98), 55-62. doi: 10.15587/1729-4061.2019.160345.

[25] Blintsov, O. V., \& Korytskyi, V. I. (2018). Syntez systemy avtomatychnoho keruvannia vertykalnym rukhom telekerovanoho pidvodnoho aparata v umovakh nevyznachenosti [Synthesis of Automatic Control System of a Remotely Operated Underwater Vehiclein Uncertainty Conditions]. Informatsiini systemy, mekhanika ta keruvannia, 19 , 28-42. doi: 10.20535/2219-3804192018169210 (in Ukrainian).

Постановка проблеми. Ефективне виконання підводних робіт неможливе без застосування підводних технологій. Деякі види робіт (наприклад, обстеження гідротехнічних споруд та корпусів суден, монтування й обстеження підводних трубопроводів) потребують можливості оперативного керування підводним апаратом та його технологічним обладнанням. Тому такі види робіт доцільно виконувати з використанням телекерованих підводних апаратів (далі - ТПА).

Динаміка ТПА як об’єкта керування описується системою нелінійних диференціальних рівнянь другого або більш високих порядків [1, с. 51]. Суттєво нелінійною є динаміка корпусу апарата та його рушійного комплексу (далі - РК). Зокрема, вплив сил тяжіння та плавучості на рух корпусу нелінійно залежить від його просторової орієнтації [2, с. 48]. На рух ТПА суттєво впливає опір підводного середовища, який описується квадратичною залежністю від швидкості руху корпусу.

Керований рух ТПА забезпечується РК, який складається 3 кількох рушійних пристроїв (далі -
РП). Конфігурація РК (кількість РП, їх взаємне розташування та просторова орієнтація) визначається вимогами до керованості певних ступенів рухливості на етапі проєктування ТПА. Як РП у ТПА застосовують системи «електродвигун - гребний гвинт».

Динаміка РП також описується системою диференціальних рівнянь 3 нелінійними електромеханічною характеристикою електродвигуна та механічною характеристикою гребного гвинта [3, с. 3]. Додатково задачу автоматизації керування рухом ТПА ускладнює нелінійність типу «обмеження», яка виникає через скінченну потужність РП [4, с. 82].

Телекерований підводний апарат як об'єкт керування складається з елементів із зосередженими (корпус) та розподіленими (кабель-трос) параметрами, визначення яких ускладнене. Так, інерційність ТПА, крім масогабаритних показників корпусу, визначається також приєднаними масами води, які суттєво залежать від геометрії поверхні корпусу ТПА. А гідродинамічний опір води рухові апарата характеризується нелінійними коефіцієнтами. Описані параметри 
визначаються шляхом проведення натурних експериментів або методами обчислювальної гідродинаміки [5, с. 10; 6, с. 121]. Окрім власних параметрів, на рух ТПА впливають невизначені зовнішні збурення, серед яких найсуттєвішими є вплив підводної течії та натяг ходового кінця кабель-троса (далі - КТ), який з'єднує ТПА із судном-носієм [7, с. 415].

Отже, вирішення задачі автоматизації просторового руху ТПА потребує синтезу багатовимірної системи автоматичного керування нелінійним об'єктом, здатної забезпечити високу точність керування в умовах невизначеності.

Аналіз останніх досліджень і публікацій. Задачі синтезу систем автоматичного керування (далі САК) рухомими об'єктами, зокрема ТПА, в сучасній літературі приділено багато уваги. Поширення набули САК, побудовані із застосуванням пропорційноінтегрально-диференціального (далі - ПІД) закону керування, теорії нечітких множин, штучних нейронних мереж, регуляторів, які функціонують у режимі «ковзання», нелінійних спостерігачів.

Регулятори на основі ПІД-закону добре вивчені та нескладно налаштовуються. Однак ефективність САК, побудованих з використанням ПІД-регуляторів, суттєво знижується при керуванні нелінійними об'єктами та впливі зовнішніх збурень, урахування яких призводить до ускладнення структури регуляторів.

Наприклад, у джерелі [8, с. 382] запропоновано САК просторовим рухом ТПА на базі ПІДрегуляторів. Нелінійний характер гідродинамічного опору запропоновано враховувати за допомогою введення коефіцієнтів, отриманих методом інтервальної лінеаризації. Варто зазначити, що якість процесів керування такої САК залежатиме як від кроку лінеаризації, так і від точності вимірювання складових частин вектора гідродинамічного опору в контрольних точках.

Багатовимірну САК на основі ПІД-регуляторів для керування ТПА із чотирма ступенями рухливості запропоновано в джерелі [9, с. 7]. Для зниження впливу збурень від КТ та шумів від сенсорів застосовано багатовимірний фільтр Калмана. Недоліком даної САК є використання законом керування параметрів РП, які здебільшого є невизначеними.

Для керування нелінійними об'єктами також застосовують регулятори на основі теорії нечітких множин. Так, авторами [10, с. 271] запропоновано нечітку САК двовимірним рухом автономного ненаселеного підводного апарата (далі - АНПА), яка враховує нелінійність РК типу «обмеження». Недоліком даної системи $є$ наявність коливань сигналів керування. Отже, ефективність застосування такої САК для керування рухом ТПА буде знижена через суттєвий вплив збурень від КТ на його рух.

У задачах керування рухомими об'єктами широкого розповсюдження набувають САК, побудовані $з$ використанням регуляторів, які працюють у режимі «ковзання». Наприклад, за вказаним методом автора- ми [11, с. 461] розроблено багатовимірний регулятор швидкості руху рухомого об'єкта. Вплив приєднаних мас на швидкісні параметри руху запропоновано компенсувати шляхом декомпозиції матриці інерційних параметрів об'єкта керування. Варто зазначити, що якість процесів керування запропонованої системи суттєво знижується при впливі зовнішніх збурень.

Задачу зниження впливу збурень на керований рух АНПА вирішено в [12, с. 3]. Авторами запропоновано для керування рухом апарата застосовувати багатовимірний регулятор у режимі «ковзання», параметри якого коригуються нечіткою ланкою. До недоліків даної системи варто віднести наявність статичної похибки керування та вплив початкових умов на характер перехідного процесу.

У [13, с. 517] запропоновано багатовимірну САК рухом ТПА на основі адаптивних регуляторів, які функціонують у режимі «ковзання». Адаптивний складник закону керування знижує вплив зовнішніх збурень та усуває вплив від зміни інерційних параметрів на рух ТПА. Недоліками системи є необхідність у попередньому визначенні обмежень градієнта збурень та посилення ефекту високочастотного перемикання сигналів керування при невдалому виборі певних параметрів закону керування.

Для керування рухомими об'єктами часто використовують САК на основі штучних нейронних мереж. Проте здебільшого структура таких САК $є$ гібридною, де нейронні мережі застосовують для надання адаптивних властивостей регулятору, який побудовано за іншим принципом.

Так, у [14, с. 2587] запропоновано САК просторовим рухом ТПА на базі нейронечіткого регулятора. Для усунення впливу нелінійності РП типу «зона нечутливості» запропоновано використовувати нечіткий компенсатор. Однак перехідний процес такої САК супроводжується коливаннями сигналів керування в широких діапазонах, що знижує якість процесу керування.

Авторами [15, с. 4] запропоновано САК просторовим рухом ТПА на базі багатовимірного адаптивного ПІД-регулятора. Підбір параметрів регулятора виконується рекурентною штучною нейронною мережею. Недоліком даної САК є складність налаштування нейронної мережі через можливість потрапляння функції втрат до локального мінімуму.

У роботі [16, с. 1640] запропоновано САК просторовим рухом АНПА на основі регуляторів в режимі «ковзання». Для зниження ефектів від впливу зовнішніх збурень запропоновано застосовувати радіальнобазову штучну нейронну мережу. Однак варто зазначити, що в усталеному режимі виникають коливання керованих параметрів, які САК усуває повільно.

У [17, с. 5] запропоновано багатовимірну САК траєкторним рухом АНПА на основі регуляторів у режимі «ковзання». Зовнішні збурення та невизначеності підводного апарата як об'єкта керування 
усуваються використанням рекурентної штучної нейронної мережі. Авторами також запропоновано метод зниження ефекту високочастотного перемикання сигналів керування. Проте застосування такого методу суттєво знижує динамічну точність системи.

Для усунення впливу невизначених зовнішніх збурень до структури САК вводять компенсатори на основі нелінійних спостерігачів. Наприклад, у роботі [18, с. 13] розроблено САК просторовим рухом ТПА із чотирма керованими ступенями рухливості на основі регулятора в режимі «ковзання». Система компенсує вплив течії та збурень від КТ за допомогою нелінійного спостерігача $з$ високим коефіцієнтом підсилення. Модель, яку реалізує спостерігач, не враховує вплив некерованих ступенів рухливості на просторовий рух ТПА, що обмежує можливість застосування розглянутої САК для керування ТПА 3 відмінними конфігураціями РК.

Авторами [19, с. 3] запропоновано САК вертикальним рухом АНПА з використанням нелінійного спостерігача на основі моделі об'єкта керування. Серед недоліків даного підходу варто зазначити наявність перерегулювань та значних затримок керованого параметра відносно задачі керування.

Виокремлення не вирішених раніше частин загальної проблеми. Аналіз літературних даних показав, що сучасні САК багатовимірними нелінійними об'єктами функціонують в умовах структурної та параметричної невизначеності об'єктів керування. Вплив обмежень об'єкта керування та зовнішніх збурень призводить до зниження якості процесів керування. Необхідність усунення зазначених проблем зумовлює актуальність даного дослідження.

Мета дослідження - розробка системи автоматичного керування просторовим рухом телекерованого підводного апарата, яка забезпечить високу якість процесів керування в умовах обмежень та невизначеності.

Для досягнення поставленої мети необхідно розв’язати такі задачі:

- синтезувати багатовимірний закон керування нелінійним об'єктом в умовах невизначеності;

- синтезувати багатовимірний задавач інтенсивності задачі керування, який забезпечить високу якість процесів керування в умовах обмежень;

- розробити систему автоматичного керування просторовим рухом телекерованого підводного апарата з високою динамічною точністю;

- дослідити роботу розробленої системи автоматичного керування.

Методи, об'єкт та предмет дослідження. Для вирішення поставлених задач застосовано такі методи дослідження: метод мінімізації локальних функціоналів для синтезу багатовимірного закону керування просторовим рухом ТПА, метод оберненої динаміки для синтезу багатовимірного задавача інтенсивності, метод числового розв'язання систем нелінійних диференціальних рівнянь для побудови імітаційної моделі ТПА та САК його рухом, метод імітаційного моделювання для дослідження роботи багатовимірної САК просторовим рухом ТПА в умовах невизначеності.

Об’єктом дослідження є рух ТПА в просторі.

Предмет дослідження - автоматизація керування просторовим рухом ТПА в умовах невизначеності.

Основний матеріал. Під час розв'язання задач навігації, орієнтації та керування рухом використовують різні системи координат. Це пояснюється відмінністю задач, а також тим, що структура та форма рівнянь суттєво залежать від вибору координатної системи [1, с. 33]. У даній роботі будемо застосовувати земну базову систему координат (далі - БСК) $O_{b} x_{b} y_{b} z_{b}$ та зв'язану систему координат (далі - ЗСК) $O_{a} x_{a} y_{a} z_{a}$.

Базова система координат орієнтована за основними напрямками на поверхні Землі. Її вісь $O_{b} y_{b} €$ продовженням радіуса-вектора, який сполучає початок системи $O_{b} 3$ деякою точкою на поверхні Землі. Осі $O_{b} x_{b}$ та $O_{b} z_{b}$ лежать у площині горизонту, вісь $O_{b} x_{b}$ завжди спрямована на північ, вісь $O_{b} z_{b}$ утворює iз першими двома осями праву прямокутну систему координат.

Зв'язана система координат повністю зв'язана 3 корпусом ТПА, переміщується й обертається разом 3 ним. Зазвичай ії центр $O_{a}$ сполучається $з$ центром мас, а осі збігаються 3 головними центральними осями інерції ТПА. Поздовжня вісь $O_{a} x_{a}$ і нормальна вісь $O_{a} y_{a}$ лежать у поздовжній площині симетрії ТПА. Перша 3 них спрямована до носової частини, друга - вертикально вгору. Поперечна вісь $O_{a} z_{a}$ утворює 3 ними праву прямокутну координатну систему i разом $з$ поздовжньою віссю $O_{a} x_{a}$ розташовується в горизонтальній площині, а разом 3 вертикальною віссю $O_{a} y_{a}-$ у поперечній площині ТПА.

Синтез закону керування розпочнемо з визначення впливу конфігурації РК на процес керованого руху ТПА. Відомо, що поступальний рух ТПА спричиняється рівнодіючою рушійних сил, яку зазвичай подають як вектор $\vec{F}_{p}=\left[F_{p(x)}, F_{p(y)}, F_{p(z)}\right]^{T}$, де $F_{p(x)}, F_{p(y)}, F_{p(z)}-$ проєкції вектора рівнодіючої рушійних сил відповідно на осі $O_{a} x_{a}, O_{a} y_{a}, O_{a} z_{a}$ ЗСК. Рівнодіюча рушійних сил формується керуючим впливом, який для ТПА запишемо як матрицю упорів його РП $F=\left[F_{1}, F_{2}, \ldots, F_{I}\right]^{T}$, де $I-$ загальна кількість РП.

Напрямок прикладання упору РП визначається його просторовою орієнтацією відносно корпусу ТПА, яку виразимо одиничним вектором $a_{i}=\left[a_{i(x)}, a_{i(y)}, a_{i(z)}\right]^{T}$. Тоді згідно з принципом суперпозиції отримаємо:

$$
\vec{F}_{p}=\sum_{i} \vec{F}_{i}, i=1,2, \ldots, I ; \quad \vec{F}_{i}=a_{i} \cdot F_{i},
$$

де $\vec{F}_{i}$ - вектор упору РП, виражений у ЗСК ТПА. Приведемо вираз (1) до матричної форми. Для цього утворимо матрицю розподілу рушійних сил $D_{p}=\left[a_{1}, a_{2}, \ldots a_{\mathrm{n}}\right]$, кожен стовпець якої є вектором просторової орієнтації відповідного РП. Отже, маємо:

$$
\vec{F}_{p}=D_{p} F
$$


Обертовий рух корпусу ТПА спричиняється рівнодіючою рушійних моментів $\vec{M}_{p}=\left[M_{p(x)}, M_{p(y)}, M_{p(z)}\right]$ ${ }^{T}$, елементи якої також є проєкціями на відповідні осі ЗСК ТПА. Вектор рівнодіючої рушійних моментів визначається у такий спосіб:

$$
\begin{aligned}
& \vec{M}_{p}=\sum_{i} \vec{M}_{i}, i=1,2, \ldots, I \\
& \vec{M}_{i}=\vec{r}_{i} \times \vec{F}_{i}=\left(\vec{r}_{i} \times a_{i}\right) \cdot F_{i},
\end{aligned}
$$

де $\vec{r}_{i}$ - координати точки розташування РП, виражені в ЗСК ТПА.

Відповідно до формули (3) утворимо матрицю розподілу рушійних моментів $D_{r}=\left[\left(\vec{r}_{1} \times a_{1}\right),\left(\vec{r}_{2} \times a_{2}\right), \ldots,\left(\vec{r}_{N} \times a_{n}\right)\right]$, кожен стовпець якої $\epsilon$ вектором напряму дії моменту, який створено РП. Приведемо вираз (3) до матричної форми:

$$
\vec{M}_{p}=D_{r} F .
$$

Сполученням матриць $D_{p}$ i $D_{r}$ отримаємо матрицю конфігурації РК D та, об’єднавши (2) і (4), отримаємо вираз для обчислення матриці рівнодіючих рушійних сил та моментів ТПА:

$$
T=\left[\begin{array}{c}
\vec{F}_{p} \\
\vec{M}_{p}
\end{array}\right]=\left[\begin{array}{c}
D_{p} \\
D_{r}
\end{array}\right] F=D F .
$$

Принцип розподілу керуючих впливів між усіма РП ТПА розглянемо на прикладі РК, вектори рівнодіючих сил та моментів якого формують ортогональні трійки. Для побудови такого РК використаємо принцип відокремлення поступального й обертового рухів ТПА та спрямуємо рушійні сили вздовж осей інерції апарата [20]. Для виконання даної умови ТПА необхідно обладнати як мінімум трьома реверсивними РП, напрямки дії яких мають бути лінійно незалежними.

У телекерованих підводних апаратах рушійні моменти утворюються під впливом рушійних сил. Щоб отримати рушійні моменти, рушійні сили необхідно продублювати та спрямувати кожну пару сил в єдиному напрямку. Сили кожної пари необхідно віддалити одна від одної вздовж осі інерції ТПА, перпендикулярної до напрямку їх дії. Моменти, які утворюються парами сил, повинні бути лінійно незалежними. Тому на конфігурацію РК ТПА додатково накладається умова взаємної перпендикулярності векторів взаємного розташування РП.

Рушійний комплекс, який задовольняє поставлені вимоги, забезпечить плавну зміну $\vec{F}_{p}$ та $\vec{M}_{p}$ у будьяких заданих напрямках. Це дасть змогу здійснювати керований рух ТПА на всіх шести ступенях вільності.

У реальних ТПА інерційність рушійних пристроїв значно менша за інерційність корпусу, тому в даній роботі динамікою РП знехтуємо, а для моделювання РК використаємо квазістаціонарну модель РП [21, с. 84]. Ураховуючи дане припущення, введемо ортогональну матрицю керуючих впливів $U=\left[u_{x}, u_{y}, u_{z}, u_{\theta}, u_{\varphi}, u_{\psi}\right]^{T}$, кожен елемент якої $\epsilon$ сигна- лом керування для певного ступеня рухливості ТПА. Тоді закон формування керуючих впливів (5) перетворюється у такий спосіб:

$$
U^{\prime}=D U,
$$

де $U=\left[u_{1}, u_{2}, \ldots, u_{I}\right]^{T}$ - матриця сигналів керування рушійними пристроями ТПА; $I$ - загальна кількість рушійних пристроїв РК.

Матриця конфігурації РК D у (6) застосовується для обчислення складових частин ортогональної матриці $U^{\prime}$ за відомих сигналів керування рушійними пристроями ТПА. Матрицю, обернену до $D$, можна застосувати для розподілення сигналів керування ступенями рухливості ТПА за рушійними пристроями. Однак обчислення матриці, оберненої до $D$, можливе лише за умови рівності кількості РП та кількості ступенів рухливості ТПА. Тому в даній роботі замість оберненої матриці $D^{-1}$ будемо використовувати псевдообернену матрицю $D^{+}$, розраховану за алгоритмом Мура-Пенроуза [22, с. 3].

Як основу для синтезу багатовимірного закону керування застосуємо одновимірний закон, отриманий у [23, с. 1223]. Для побудови багатовимірної САК рухом ТПА введемо матрицю позиційних кінематичних параметрів ТПА $R=[x, y, z, \theta, \varphi, \psi]^{T}$, де $\theta, \varphi, \psi-$ відповідно кути крену, курсу та диференту ТПА. Також введемо матрицю бажаних значень позиційних кінематичних параметрів ТПА $R_{g}=\left[x_{g}, y_{g}, z_{g}, \theta_{g}, \varphi_{g}, \Psi_{g}\right]^{T}$.

Варто зазначити, що складники матриць $R$ та $R_{g}$ подаються у відношенні до БСК, тому різницю матриць $R$ та $R_{g}$ необхідно привести до ЗСК. Для цього скористаємося матрицею зв'язку позиційних та швидкісних кінематичних параметрів ТПА, яка має такий вигляд [2, с. 47]:

$$
K_{V}=\left[\begin{array}{cc}
K_{v} & 0_{3 \times 3} \\
0_{3 \times 3} & K_{\omega}
\end{array}\right] .
$$

У (7) $K_{v}$ - матриця зв'язку між ЗСК та БСК такого вигляду:

$$
K_{v}=\left[\begin{array}{ccc}
\cos \phi \cos \psi & (\sin \phi \sin \theta- & (\cos \phi \sin \psi \sin \theta+ \\
& -\cos \phi \sin \psi \cos \theta) & +\sin \phi \cos \theta) \\
\sin \psi & \cos \psi \cos \theta & -\cos \psi \sin \theta \\
-\sin \phi \cos \psi & (\sin \phi \sin \psi \cos \theta+ & (\cos \phi \cos \theta- \\
& +\cos \phi \sin \theta) & -\sin \phi \sin \psi \sin \theta)
\end{array}\right] .
$$

Кінематична матриця зв'язку обертового руху $K_{\omega}$ iз (7) має такий вигляд:

$$
K_{\omega}^{-1}=\left[\begin{array}{ccc}
1 & \sin \psi & 0 \\
0 & \cos \psi \cos \theta & \sin \theta \\
0 & -\cos \psi \sin \theta & \cos \theta
\end{array}\right] .
$$

Використаємо (7) та отримаємо таке:

$$
E=K_{V}^{-1}\left(R_{g}-R\right) .
$$

Також визначимо матриці коефіцієнтів градієнтного пошуку $K=\left[k_{x}, k_{y}, k_{z}, k_{\theta}, k_{\varphi}, k_{\psi}\right]^{T}$, $H=\left[h_{x}, h_{y}, h_{z}, h_{\theta}, h_{\varphi}, h_{\psi}\right]^{T}$ та матрицю постійних значень часу еталонної моделі регулятора $T_{r}=\operatorname{diag}\left\{\tau_{r(x)}\right.$, $\left.\tau_{r(y)}, \tau_{r(z)}, \tau_{r(\theta)}, \tau_{r(\varphi)}, \tau_{r(\psi)}\right\}$. 3 урахуванням (6)-(8) отрима- 
ємо такий закон керування просторовим рухом ТПА:

$$
\begin{gathered}
U:=D^{+}\left(\Lambda K \circ\left[E+2\left(T_{r}^{-1} E_{i}\right)\right]+\mathrm{X}_{i}\right) ; \quad \mathrm{X}_{i}:=I_{\mathrm{X}}\left(\mathrm{X}, s, I_{\mathrm{X}}, t\right) ; \\
E_{i}:=I_{E}\left(E, s, I_{E}, t\right) ; \quad \mathrm{X}:=\Lambda K \circ\left(T_{r}^{-2} E_{i}\right)-H \circ(D U) ; \\
\min (K)>0 ; \quad \Lambda=\operatorname{sign}\left(\nabla \ddot{R}\left(U^{\prime}\right)\right),
\end{gathered}
$$

де $U$ - матриця сигналів керування; $E_{i}$ та $\mathrm{X}_{i}-$ результати інтегрування матриць $E$ і X відповідно; символом « ${ }^{\circ}$ позначено операцію обчислення добутку Адамара, тобто поелементне перемноження матриць; символом « $\nabla$ » позначено операцію визначення градієнта функції $\ddot{R}\left(U^{\prime}\right)$; точкою позначено операцію взяття похідної за часом $t$.

Для усунення інтегрального насичення САК складові матриць $E$ та X будемо інтегрувати за умовою, яка запропонована в [23, с. 1223]. А з урахуванням припущення про квазістаціонарний режим роботи РП система керування, яку побудовано за законом (9) з використанням еталонної моделі, порядок якої не нижче другого, забезпечить високу динамічну точність при керуванні ТПА в умовах невизначеності [24, с. 57].

Для забезпечення високої якості процесів керування просторовим рухом ТПА необхідно враховувати обмеження його РК. У [25, с. 33] було запропоновано одновимірний задавач інтенсивності (далі - 3I) на основі лінійної динамічної ланки другого порядку та регулятора, який побудовано за принципом оберненої задачі динаміки.

Можливість застосування даного 3І разом із законом керування (9) забезпечимо введенням матриць вихідних змінних $R$, сигналів керування $U_{1}$, постійних часу $T_{1}$ та коефіцієнтів передачі $K_{1}$ внутрішньої моделі об'єкта керування 3І.

Тоді внутрішня модель об'єкта керування набуде такого вигляду:

$$
\begin{aligned}
& R_{t}=\left[x_{t}, y_{t}, z_{t}, \theta_{t}, \phi_{t}, \psi_{l}\right]^{T} ; \\
& U_{t}=\left[u_{t(x)}, u_{t(y)}, u_{t(z)}, u_{t(\theta)}, u_{t(\phi)}, u_{t(\psi)}\right]^{T} ; \\
& T_{1}=\operatorname{diag}\left\{\tau_{\mathrm{t}(x)}, \tau_{\mathrm{l}(y)}, \tau_{\mathrm{t}(\mathrm{z})}, \tau_{\mathrm{t}(\theta)}, \tau_{\mathrm{t}(\varphi)}, \tau_{\mathrm{t}(\psi)}\right\} \text {; } \\
& K_{\mathrm{l}}=\left[k_{\mathrm{l}(x)}, k_{\mathrm{l}(y)}, k_{\mathrm{l}(\mathrm{z})}, k_{\mathrm{l}(\theta)}, k_{\mathrm{l}(\varphi)}, k_{\mathrm{l}(\psi)}\right]^{T} \text {; } \\
& \ddot{R}_{t}=T_{i}^{-2}\left(K_{t} \circ U_{t}-2 \mathrm{Z} \circ\left(T \dot{R}_{t}\right)-R_{i}\right),
\end{aligned}
$$

де $\mathrm{Z}=\left[\zeta_{x}, \zeta_{y}, \zeta_{z}, \zeta_{\sharp}, \zeta_{\phi}, \zeta_{\psi}\right]^{T}-$ матриця коефіцієнтів демпфування внутрішньої моделі об'єкта керування в 3І.

Введемо матрицю постійних значень часу еталонної моделі $T_{m}$ та отримаємо багатовимірну версію внутрішнього регулятора в 3І:

$$
\begin{aligned}
& R_{l d}=\left[x_{\imath d}, y_{l d}, z_{t d}, \theta_{t d}, \phi_{t d}, \psi_{t d}\right] ; \\
& T_{m}=\operatorname{diag}\left\{\tau_{m(x)}, \tau_{m(y)}, \tau_{m(z)}, \tau_{m(,)}, \tau_{m(\phi)}, \tau_{m(\grave{\mathrm{E}})}\right\} ; \\
& \left.\begin{array}{c}
\ddot{R}_{l d}=\ddot{R}_{g}+2 \mathrm{Z} \circ\left(T_{m}^{-1} \dot{E}_{l}\right)+T_{m}^{-2} E_{l} ; \\
E_{\imath}=R_{g}-R_{l},
\end{array}\right\},
\end{aligned}
$$

де $R_{\mathrm{s}}$ - матриця бажаних значень вихідних величин 3I.

Введемо функцію обмеження $\operatorname{sat}\left(X, X_{\lim }\right)$, кожний елемент якої обчислюється за формулою

$$
f\left(x, x_{\lim }\right)=\left\{\begin{array}{l}
x_{\lim }, \text { якщо } x>x_{\lim } ; \\
-x_{\lim }, \text { якщо } x<-x_{\lim } \\
x, \text { інакше },
\end{array}\right.
$$

де $X$ - матриця параметрів, що обмежуються; $X_{\lim }$ - матриця заздалегідь визначених обмежень; $x, x_{\lim }$ - елементи матриць $X$ та $X_{\lim }$ відповідно.

У задачах керування рухом ТПА розмірність матриць $X$ та $X_{\lim }$ визначається кількістю ступенів рухливості апарата. Функцію (12) застосуємо для врахування обмежень об'єкта керування в реалізації ЗІ:

$$
\begin{gathered}
U_{\imath}=\operatorname{sat}\left(\operatorname { d i a g } ( K _ { t } ) ^ { - 1 } \left[T_{\imath}^{2} \operatorname{sat}\left(\ddot{R}_{l d}, \ddot{R}_{\text {lim }}\right)+\right.\right. \\
\left.\left.+2 \mathrm{Z} \circ\left[T_{\imath} \operatorname{sat}\left(\dot{R}_{g}, \dot{R}_{\text {lim }}\right)\right]+\operatorname{sat}\left(R_{g}, R_{\text {lim }}\right)\right], U_{\text {lim }}\right),
\end{gathered}
$$

де $U_{\text {lim }}, R_{\text {lim }}, \dot{R}_{\text {lim }}, \ddot{R}_{\text {lim }}$ - матриці обмежень відповідно сигналів керування, керованих змінних об'єкта керування, а також першої та другої їх похідних.

До складу одновимірної САК вертикальним рухом ТПА, запропонованої в [25, с. 35], також входить коригувальна ланка, яка обмежує зростання значення вихідної змінної ЗІ на період до виходу системи 3 режиму насичення. Для забезпечення можливості застосування такої ланки у складі САК просторовим рухом ТПА запишемо фазовий простір задачі керування матрицею $R_{p}=\left[R_{g}, \dot{R}_{g}, \ddot{R}_{g}\right]$ та введемо матрицю коригованих значень фазових змінних $\bar{R}_{p}=\left[\bar{R}_{g}, \boldsymbol{R}_{g}, \boldsymbol{R}_{g}\right]$. На основі коригувальної ланки із [25] сформуємо блок коригування задачі для 3I:

$$
\begin{aligned}
& i=[x, y, z, \theta, \phi, \psi] ; \\
& \hat{R}_{p(i)}=\left\{\begin{array}{lll}
{\left[\begin{array}{lll}
r_{i} & 0 & 0
\end{array}\right],} & \text { якщо } s=\text { true } \wedge p_{i}=\text { true; } \\
{\left[\begin{array}{lll}
r_{g(i)} & \dot{r}_{g(i)} & \ddot{r}_{g(i)}
\end{array}\right], \text { інакше; }}
\end{array}\right. \\
& c_{i}=\left(\left[r_{t(i)}>\left(r_{g(i)}+\gamma_{i}\right)\right] \wedge\left[r_{t(i)}>\left(r_{i}+\gamma_{i}\right)\right]\right) \vee \\
& \vee\left(\left[r_{t(i)}<\left(r_{g(i)}-\gamma_{i}\right)\right] \wedge\left[r_{t(i)}<\left(r_{i}-\gamma_{i}\right)\right]\right) ; \\
& p_{i}=\left\{\begin{array}{l}
\text { false, при } c_{i}=\text { true } \\
\text { true, iнакше, }
\end{array}\right.
\end{aligned}
$$

де $p_{i}$ - ознака, яка показує, чи знаходиться числове значення виходу 3І $r_{t(i)}$ між значеннями параметрів $r_{g(i)}$ та $r_{i} ; \gamma_{i}$ - допустиме значення відхилення параметра $r_{t(i)}$ від значень параметрів $r_{g(i)}$ i $r_{i}$.

Введемо матрицю масштабування постійних значень часу еталонної моделі внутрішнього регулятора $K_{m}=\left[k_{m(x)}, k_{m(y)}, k_{m(z)}, k_{m(\theta)}, k_{m(\varphi)}, k_{m(\psi)}\right]^{T}$ та забезпечимо сповільнення багатовимірного 3І в режимі насичення:

$$
T_{m(i)}=\left\{\begin{array}{l}
k_{m(i)} \tau_{m(i)}, \text { при } s=\text { true } \wedge p_{i}=\text { true; } \\
\tau_{m(i)}, \text { інакше }
\end{array}\right.
$$

де $\tau_{m(i)}$ - елемент матриці масштабованих постійних часу еталонної моделі 3І $T_{m}$. Для забезпечення стійкості САК коефіцієнти масштабування в матриці $K_{m}$ необхідно обирати так, щоб виконувалася умова $\min \left(K_{m}\right)>>1$.

Таким чином, САК просторовим рухом ТПА має структуру, яку зображено на рис. 1. 


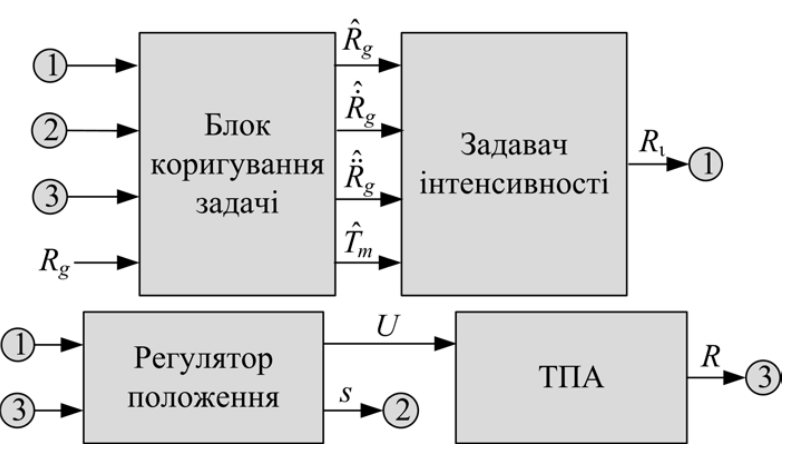

Рис. 1. Структура САК просторовим рухом ТПА

Керування рухом ТПА здійснює регулятор положення, який реалізує закон керування (9) та визначає матрицю похибок керування за виразами (7)-(8). Матрицю задач керування для регулятора положення обчислює задавач інтенсивності, який складається 3 внутрішніх моделі об'єкта керування (10) та регулятора (11), закон керування якого з урахуванням виразу (12) набуває вигляду виразу (13). Матриця задач керування та налаштування 3І розраховуються блоком коригування задачі за виразами (14)-(16).

Динаміку перехідних процесів САК просторовим рухом ТПА було досліджено методом комп'ютерного моделювання 3 використанням математичної моделі

Таблиця 1. Основні параметри математичної моделі просторового руху ТПА

\begin{tabular}{|c|c|c|}
\hline Параметр & $\begin{array}{c}\text { Одиниця } \\
\text { вимірювання }\end{array}$ & Значення \\
\hline $\begin{array}{l}\text { Форма корпусу: } \\
\text { - довжина; } \\
\text { - висота; } \\
\text { - ширина }\end{array}$ & $\begin{array}{l}\mathrm{M} \\
\mathrm{M} \\
\mathrm{M}\end{array}$ & $\begin{array}{c}\text { Тривісний } \\
\text { еліпсоїд: } \\
1,22 \\
0,54 \\
0,6 \\
\end{array}$ \\
\hline Маса ТПА & Кг & 97 \\
\hline $\begin{array}{l}\text { Водотоннажність } \\
\text { ТПА }\end{array}$ & $\mathrm{M}^{3}$ & 0,097 \\
\hline Плавучість ТПА & $\mathrm{H}$ & 0 \\
\hline $\begin{array}{l}\text { Координати точки } \\
\text { прикладання сили } \\
\text { плавучості в ЗСК }\end{array}$ & M & $\{0,0,2,0\}$ \\
\hline Довжина КТ & $\mathrm{M}$ & 150 \\
\hline $\begin{array}{l}\text { Координати точки } \\
\text { кріплення КТ у ЗСК }\end{array}$ & M & $\{-0,25,0,0\}$ \\
\hline $\begin{array}{l}\text { Координати } \\
\text { розміщення РП у } \\
\text { ЗСК: } \\
\text { - лівий; } \\
\text { - правий; } \\
\text { - вертикальний; } \\
\text { - лагів }\end{array}$ & $\begin{array}{l}\mathrm{M} \\
\mathrm{M} \\
\mathrm{M} \\
\mathrm{M}\end{array}$ & $\begin{array}{c}\{-0,55,0,-0,2\} \\
\{-0,55,0,0,2\} \\
\{0,0,25,0\} \\
\{0,3,0,0,25\}\end{array}$ \\
\hline $\begin{array}{l}\text { Координати векторів } \\
\text { напряму рушійних } \\
\text { сил РП ЗСК: } \\
\text { - лівий; } \\
\text { - правий; } \\
\text { - вертикальний; } \\
\text { - лагів }\end{array}$ & $\begin{array}{l}\mathrm{M} \\
\mathrm{M} \\
\mathrm{M} \\
\mathrm{M} \\
\end{array}$ & $\begin{array}{c}\{1,0,0\} \\
\{1,0,0\} \\
\{0,-1,0\} \\
\{0,0,1\}\end{array}$ \\
\hline Потужність РП & $\mathrm{BT}$ & 500 \\
\hline Швидкість течії & $\mathrm{M} / \mathrm{c}$ & $\{-0,25,0,0\}$ \\
\hline
\end{tabular}

руху ТПА, яку запропоновано в [2, с. 46]. Основні параметри математичної моделі відповідають параметрам ТПА проєкту «Гідрограф» (Україна, Національний університет кораблебудування імені адмірала Макарова) та зведені в табл. 1.

Для ТПА з параметрами, які зазначено в табл. 1 , типовими значеннями постійних часу є 2 с і 1 с відповідно для поступальних та обертових ступенів рухливості. Оскільки задавач інтенсивності дає змогу підвищити швидкодію САК, обрано такі значення постійних часу еталонної моделі регулятора положення: $T_{r}=\operatorname{diag}\{0,75,0,75,0,75,0,5,0,5,0,5\} \mathrm{c}$. На основі критеріїв, запропонованих у [23, с. 1221], обрано такі параметри регулятора: $c=5 ; n=10$; $T_{\Delta}=0,01 \mathrm{c} ; K=\left[137,8 \mathrm{M}^{-1}, 58,7 \mathrm{M}^{-1}, 66,7 \mathrm{M}^{-1}, 1\right.$ рад $^{-1}, 5$ $0 \mathrm{paд}^{-1}, 1$ рад $\left.^{-1}\right]^{T} H=[13,3,13,3,13,3,20,20,20]^{T}$.

У процесі проєктування ТПА звичайно використовують емпіричну залежність $l_{u} \geq 2,5 y_{\lim }$, де $l_{u}$ - довжина КТ; $y_{\lim }$ - максимально допустима робоча глибина занурення ТПА. За результатами комп'ютерного моделювання роботи ТПА на граничній глибині визначено матриці обмежень сигналів керування внутрішнього регулятора 3І та керованих величин: $U_{\lim }=[130 \mathrm{M}, 60 \mathrm{M}, 100 \mathrm{M}, \pi / 2$ рад, $\pi$ рад, $\pi / 2$ рад] $]^{T} ; R_{\lim }=U_{\lim }$. Матрицю обмежень швидкості руху ТПА визначено за результатами комп'ютерного моделювання руху підводного апарата за максимальних керуючих впливів: $\dot{R}_{\lim }=[1,4 \mathrm{~m} / \mathrm{c}, 0,5 \mathrm{~m} / \mathrm{c}, 0,6 \mathrm{~m} / \mathrm{c}$, 0 рад/c, 0,3 рад/c, 0 рад/c] $]^{T}$. Прискорення руху ТПА як об'єкта керування зазвичай не обмежене, тому матриця обмежень складників прискорення руху підводного апарата набуває вигляду $\ddot{R}_{l i m}=\left[\infty \mathrm{M} / \mathrm{c}^{2}, \infty \mathrm{M} / \mathrm{c}^{2}\right.$,

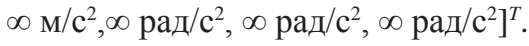

Оскільки точне визначення динамічних характеристик ТПА ускладнене, обрано такі параметри внутрішньої лінійної моделі в $3 \mathrm{I}: \mathrm{Z}=[1,1,1,1,1,1]^{T}$; $K_{1}=[1,1,1,1,1,1]^{T} ; T_{1}=T_{r}$. Постійні значення часу еталонної моделі внутрішнього регулятора в 3І також визначено з налаштувань регулятора положення: $T_{m}=T_{r}$.

Для забезпечення задовільної якості перехідних процесів та високої швидкодії САК динаміку обертових ступенів рухливості ЗІ порівняно з поступальними було сповільнено збільшенням значень відповідних коефіцієнтів у матриці $K_{m}$. Також для усунення перерегулювань сповільнено динаміку вертикального ступеня рухливості 3І порівняно з маршовим та лаговим. Таким чином, ураховуючи обмеження $\min \left(K_{m}\right)>>1$, обрано наступні значення коефіцієнтів масштабування постійних значень часу внутрішнього регулятора в 3I: $K_{m}=[4,10,4,12,12,12]^{T}$ с. Допустимі граничні значення відхилень керованих параметрів 3І було обрано так: $\Gamma=[0,01$ м, 0,01 м, $\left.0,01 \mathrm{M}, 1^{\circ}, 1^{\circ}, 1^{\circ}\right]^{T}$.

Якість процесу керування оцінюватимемо за такими показниками: перерегулювання, похибка керування, тривалість перехідного процесу. Відносну похибку керування будемо визначати відносно максимально допустимих значень керованих величин 3 


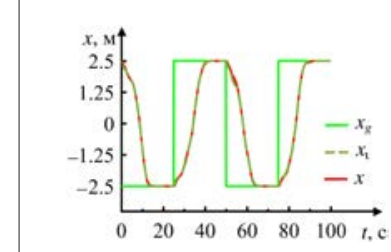

a)

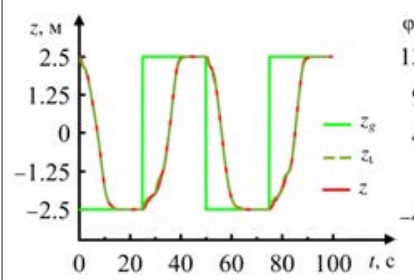

в)

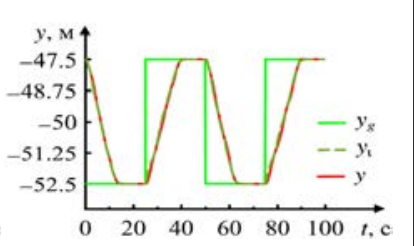

б)

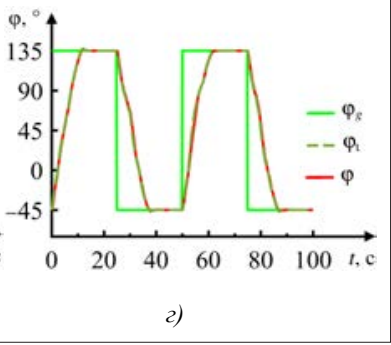

Рис. 2. Динаміка керованих ступенів рухливості ТПА при ступінчатій зміні задачі керування: a) маршовий рух; б) вертикальний рух; в) лаговий рух; г) обертовий рух
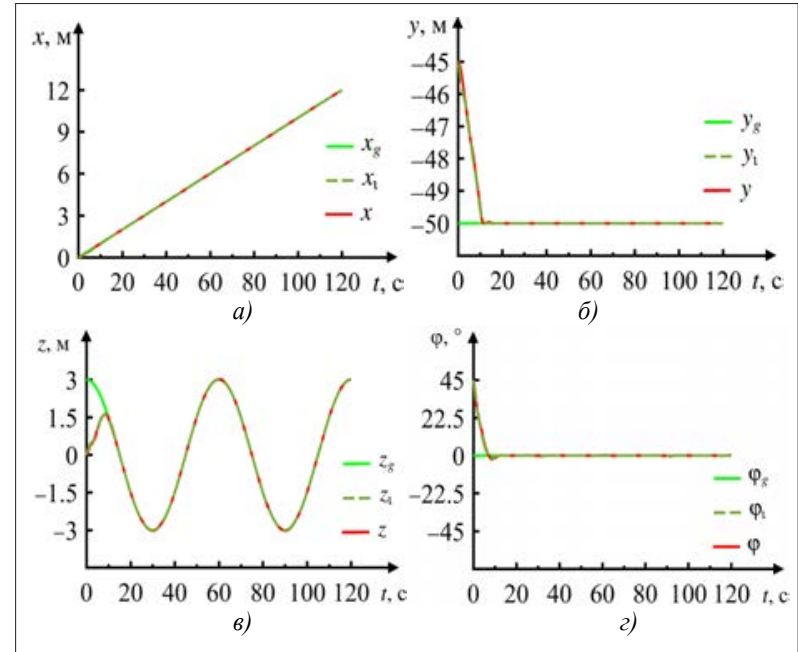

Рис. 3. Динаміка керованих ступенів рухливості ТПА при зміні задачі керування за гармонічним законом: a) маршовий рух; б) вертикальний рух; в) лаговий рух; г) обертовий рух матриці $R_{\lim }$. Тривалість перехідного процесу визначимо як проміжок часу від моменту виходу САК з режиму насичення до моменту, коли значення найбільшої з відносних похибок керування стає меншим від $1 \%$.

Динаміку перехідних процесів САК для задачі керування, яка змінюється за ступінчастим законом, зображено на рис. 2 .

На початку перехідного процесу САК входить до режиму насичення, в якому маршовий та лаговий ступені рухливості сповільнені відносно вертикального. Найшвидше задачу керування САК відпрацьовує за курсом. Після виходу САК з режиму насичення поступальні ступені рухливості відпрацьовують задачу керування без перерегулювань. Перерегулювання САК за обертовим ступенем рухливості не перевищують $1,7 \%\left(3^{\circ}\right)$. Варто відзначити зменшення рівня перерегулювань із часом. Тривалість перехідного процесу після виходу САК з режиму насичення не перевищує 4 c.

Динамічну точність запропонованої САК було оцінено шляхом подачі на іiі вхід задачі керування, яка змінюється за гармонічним законом. Графіки процесу керування зображено на рис. 3 .

Після виходу з режиму насичення САК забезпечує перехідний процес, тривалість якого не перевищує 4 с. При цьому також спостерігаються перерегулювання за курсом, які не перевищують 1,7\% $\left(3^{\circ}\right)$. Перерегулювання за поступальними ступенями рухливості відсутні. Після завершення перехідного процесу САК відпрацьовує задачу керування, що динамічно змінюється, з високою точністю. Найбільша відносна похибка САК за поступальними ступенями не перевищує $0,07 \%$ (0,08 м), а за обертовим - 0,3\% $\left(0,5^{\circ}\right)$. Отже, запропонована САК забезпечує високу динамічну точність процесів керування рухом ТПА в умовах невизначеності та впливу збурень.

Обговорення отриманих результатів. Розроблена САК реалізує багатовимірний закон керування на основі методу мінімізації локальних функціоналів, який не використовує інформації про параметри ТПА, що забезпечує високу динамічну точність в умовах невизначеності. При цьому синтезований закон керування реалізується на основі матриці позиційних кінематичних параметрів ТПА і не передбачає використання їі похідних.

Застосування у складі САК багатовимірного 3I дозволяє забезпечити високі показники якості керування рухом ТПА в умовах обмеження керуючих впливів. Однак варто враховувати, що висока точність керування досягається завдяки збільшенню постійних значень часу задавача інтенсивності для виведення системи з режиму насичення.

Запропонована САК реалізує розподілення сигналів керування ступенями рухливості ТПА завдяки введенню до багатовимірного закону керування матриці конфігурації рушійного комплексу. Це забезпечує можливість використання даної системи для керування ТПА з довільною конфігурацією рушійного комплексу.

ВИСНОВКИ. 1. Синтезовано багатовимірний закон керування телекерованим підводним апаратом в умовах невизначеності, отриманий методом мінімізації локального функціоналу. До його складу введено матрицю конфігурації рушійного комплексу, що дає змогу керувати просторовим рухом телекерованого підводного апарата 3 довільною конфігурацією рушійного комплексу.

2. Синтезовано задавач інтенсивності задачі керування на основі багатовимірної лінійної моделі об’єкта керування та інверсного регулятора. Його використання у складі системи автоматичного керування дозволяє покращити якість процесів керування рухом апарата в умовах обмежень.

3. На основі запропонованого закону керування та багатовимірного задавача інтенсивності синтезовано систему автоматичного керування просторовим рухом телекерованого підводного апарата високої дина- 
мічної точності. Система забезпечує високу точність керування просторовим рухом телекерованого підводного апарата в умовах невизначеності, обмежень керуючих впливів та впливу зовнішніх збурень.

4. Досліджено роботу запропонованої системи автоматичного керування методом математичного моделю- вання просторового руху телекерованого підводного апарата. Система забезпечує перехідні процеси з відносною похибкою не більше 0,3\%. Тривалість перехідних процесів після виходу системи з режиму насичення та до потрапляння в 1\% коридор не перевищує 4 с, що є цілком достатнім для автоматичного керування малогабаритними ТПА.

\section{Список літератури:}

[1] Antonelli G. (2018). Underwater Robots. Springer Tracts in Advanced Robotics. DOI: 10.1007/978-3-319-77899-0.

[2] Korytskyi V.I. (2018) Improvement of the Mathematical Model of Spatial Motion of a Remotely Operated Underwater Vehicle with Technological Equipment. Shipbuilding and Marine Infrastructure, 1 (9), 44-52. doi: 10.15589/ SMI.2018.01.06.

[3] Aras M.S., Abdullah, S.S., Rahman A.A., \& Aziz M.A. (2013). Thruster Modelling for Underwater Vehicle Using System Identification. International Journal of Advanced Robotic Systems, 10 (252), 12. DOI: 10.5772/56432.

[4] Liu Z., Zhang Y., Yu X., \& Yuan C. (2016). Unmanned surface vehicles: An overview of developments and challenges. Annual Reviews in Control, 41, 71-93. DOI: 10.1016/j.arcontrol.2016.04.018.

[5] Stern F., Yang J., Wang Z., Sadat-Hosseini H., Mousaviraad M., Bhushan S., \& Xing T. (2013). Computational ship hydrodynamics: nowadays and way forward. International Shipbuilding Progress, 60, 3-105. DOI: 10.3233/ ISP-130090.

[6] Fossen T.I. (2011). Handbook of Marine Craft Hydrodynamics and Motion Control. John Wiley and Sons. DOI: 10.1002/9781119994138.

[7] Park J., \& Kim N. (2015). Dynamics modeling of a semi-submersible autonomous underwater vehicle with a towfish towed by a cable. International Journal of Naval Architecture and Ocean Engineering, 7, 409-425. DOI: 10.1515/ ijnaoe-2015-0029.

[8] Gayvoronskiy S.A., Khozhaev I.V. \& Ezangina T.A. (2017). Motion Control System for a Remotely Operated Vehicle with Interval Parameters. International Journal of Mechanical Engineering and Robotics Research, 6:5, 378384. DOI: 10.18178/ijmerr.6.5.378-384.

[9] Rúa S., \& Vásquez R.E. (2016). Development of a low-level control system for the ROV Visor3. International Journal of Navigation and Observation, 12. DOI: 10.1155/2016/8029124.

[10] Yu C., Xiang X., Zhang Q., \& Xu G. (2018). Adaptive Fuzzy Trajectory Tracking Control of an Under-Actuated Autonomous Underwater Vehicle Subject to Actuator Saturation. International Journal of Fuzzy Systems, 20 (1), 269-279. DOI: 10.1007/s40815-017-0396-9.

[11] Herman P., \& Adamski W. (2017). Non-adaptive velocity tracking controller for a class of vehicles. Bulletin of the Polish Academy of Sciences. Technical Sciences, 65:4, 459-468. DOI: 10.1515/bpasts-2017-0051.

[12] Wang, G., Xu, G., Liu, G., Wang, W., \& Li, B. (2019). Fuzzy Iterative Sliding Mode Control Applied for Path Following of an Autonomous Underwater Vehicle with Large Inertia. Mathematical Problems in Engineering, 14. DOI: $10.1155 / 2019 / 8650243$.

[13] Guerrero, J., Torres, J., Creuze, V., \& Chemori, A. (2019). Trajectory tracking for autonomous underwater vehicle: An adaptive approach. Ocean Engineering, 172, 511-522. DOI: 10.1016/j.oceaneng.2018.12.027.

[14] Xia, G., Pang, C., \& Xue, J. (2015). Fuzzy neural network-based robust adaptive control for dynamic positioning of underwater vehicles with input dead-zone. Journal of Intelligent and Fuzzy Systems, 29, 2585-2595. DOI: 10.3233/ IFS-151961.

[15] Hernández-Alvarado, R., García-Valdovinos, L. G., Salgado-Jiménez, T., Gómez-Espinoza, A., \& FonsecaNavarro, F. (2016). Neural Network-Based Self-Tuning PID Control for Underwater Vehicles. Sensors, $16,18$. DOI: $10.3390 / \mathrm{s} 16091429$.

[16] Chu Z., Zhu D., \& Luo C. (2017). Adaptive Neural Sliding Mode Trajectory Tracking Control for Autonomous Underwater Vehicle Without Thrust Model. Materials of 13th IEEE Conference on Automation Science and Engineering. Xi an, China, 1639-1644. DOI: 10.1109/COASE.2017.8256339.

[17] Yang C., Yao F., \& Zhang M. (2018). Adaptive Backstepping Terminal Sliding Mode Control Method Based on Recurrent Neural Networks for Autonomous Underwater Vehicle. Chinese Journal of Mechanical Engineering, 31 (110), 16. DOI: 10.1186/s10033-018-0307-5.

[18] Li X., Zhao M., \& Ge T. (2018). A Nonlinear Observer for Remotely Operated Vehicles with Cable Effect in Ocean Currents. Applied Sciences, 8:6, 27. doi: 10.3390/app8060867.

[19] Yao F., Yang C., Liu X., \& Zhang M. (2018). Experimental Evaluation on Depth Control Using Improved Model Predictive Control for Autonomous Underwater Vehicle (AUVs). Sensors, 18, 16. DOI: 10.3390/s18072321.

[20] Блінцов О.В. (2018). Системи автоматичного керування рухом підводних комплексів з гнучкими зв'язками : навчальний посібник. Миколаїв : Національний університет кораблебудування імені адмірала Макарова. 
[21] Павлов Г.В., Блінцов О.В. (2008). Синтез нейромережних моделей електрорушійного пристрою для задач керування квазістаціонарним рухом прив'язного підводного апарата : збірник наукових праць Національного університету кораблебудування, 5 (422), 81-86.

[22] Пшихопов В.Х., Медведев М.Ю. Федоренко, Р.В., Гуренко Б.В., Чуфистов В.М., Шевченко В.А. (2014). Алгоритмы многосвязного позиционно-траекторного управления подвижными объектами. Инженерный вестник Дона, 31 (3), 17. URL: http://www.ivdon.ru/uploads/article/pdf/ IVD_26_Pshikhopov.pdf_ddf06b616a.pdf.

[23] Blintsov O., Korytskyi V., \& Sokolov V. (2019). Synthesis of Precise Automatic Control System of a Second Order Object in Uncertainty Conditions. ARPN Journal of Engineering and Applied Sciences, 14 (6), $1218-1228$. Retrieved from http://www.arpnjournals.org/jeas/research_papers/rp_2019/jeas_0319_7671.pdf.

[24] Blintsov O.V. Burunina Zh.Yu., Voitasyk A.M. (2019). Improvement of the Inverse Dynamics Method for HighPrecision Control of Nonlinear Objects under Conditions of Uncertainty. Eastern-European Journal of Enterprise Technologies, 2/2 (98), 55-62. DOI: 10.15587/1729-4061.2019.160345.

[25] Блінцов О.В., Корицький В.І. (2018). Синтез системи автоматичного керування вертикальним рухом телекерованого підводного апарата в умовах невизначеності. Інформаційні системи, механіка та керування, 19, 28-42. DOI: 10.20535/2219-3804192018169210.

(C) О. В. Блінцов, В. І. Корицький 